\title{
Author Correction: Blood-brain barrier permeable nano immunoconjugates induce local immune responses for glioma therapy
}

\author{
Anna Galstyan, Janet L. Markman (1D, Ekaterina S. Shatalova, Antonella Chiechi, Alan J. Korman, \\ Rameshwar Patil (D, Dmytro Klymyshyn, Warren G. Tourtellotte, Liron L. Israel, Oliver Braubach (D, \\ Vladimir A. Ljubimov, Leila A. Mashouf, Arshia Ramesh, Zachary B. Grodzinski, Manuel L. Penichet, \\ Keith L. Black, Eggehard Holler (D), Tao Sun, Hui Ding, Alexander V. Ljubimov \& Julia Y. Ljubimova
}

Correction to: Nature Communications https://doi.org/10.1038/s41467-019-11719-3, published online 28 August 2019.

The original version of this Article contained an error in Fig. 7h. The mice labelled as treated with a P/AP-2/a-PD-1+P/AP-2/a-CTLA4 construct were inadvertently treated with a P/AP-2/a-CTLA-4+P/a-PD-1/AON c-Myc construct. The experiment has now been repeated with the correct $\mathrm{P} / \mathrm{AP}-2 / \mathrm{a}-\mathrm{CTLA}-4+\mathrm{P} / \mathrm{AP}-2 / \mathrm{a}-\mathrm{PD}-1$ construct.

In addition, in the original version of Fig. $7 \mathrm{f}$ and $\mathrm{g}$, some mice were excluded from survival analysis due to extracranial tumor growth or possible neurogenic shock. The mice that were excluded are now shown in the Supplementary Data associated with this correction.

These errors have been corrected in both the PDF and HTML versions of the Article.

Published online: 26 November 2020

\section{Additional information}

Supplementary information is available for this paper at https://doi.org/10.1038/s41467-020-20129-9.

\footnotetext{
(c) Open Access This article is licensed under a Creative Commons Attribution 4.0 International License, which permits use, sharing, adaptation, distribution and reproduction in any medium or format, as long as you give appropriate credit to the original author(s) and the source, provide a link to the Creative Commons license, and indicate if changes were made. The images or other third party material in this article are included in the article's Creative Commons license, unless indicated otherwise in a credit line to the material. If material is not included in the article's Creative Commons license and your intended use is not permitted by statutory regulation or exceeds the permitted use, you will need to obtain permission directly from the copyright holder. To view a copy of this license, visit http://creativecommons.org/licenses/by/4.0/.
}

(C) The Author(s) 2020 